\title{
Change of Surface Temperature and Far-infrared Emissivity in Ceramics Manufactured from a Board Mixed with Sawdust and Mandarin Peel ${ }^{1}{ }_{(\leftrightarrow P R}$
}

\author{
Jung-Woo Hwang ${ }^{2} \cdot$ Seung-Won $\mathrm{Oh} \oplus^{2, \dagger}$
}

\begin{abstract}
The aim of the study is to use the by-products sawdust, formed during sawing and mandarin peel which are agricultural by products. The boards were manufactured by mixing the sawdust and mandarin peel at different mixing ratio and density. In terms of changes in surface temperature of ceramics, we could found that the velocity was fast in the early time of heat transfer until 10 minutes and after that the velocity increased but not very fast. At the elapsed time of 30 minutes, the surface temperature of ceramics increased with the carbonization temperature and rate of mandarin peel addition did not influence the surface temperature. Far - infrared emissivity had no constant tendency in rate of mandarin peel addition, it decreased with increase of carbonization temperature.
\end{abstract}

Keywords: composite board, mandarin peel, surface temperature, far-infrared emissivity

\section{INTRODUCTION}

The policies for the protection of domestic wood industries in countries with wood resources have not been established because of which the lack of wood resources is likely to continue. Therefore, eco-friendly materials must be developed using the available wood resources such as waste wood resources, construction waste, and thinned logs as domestic wood prices are rising every year. To overcome this issue, a domestic timber supply and demand system must be developed that can substitute for wood fiber and other fiber resources. In addition, new material resources must be developed using other agricultural by-products. Annual production of domestic mandarins is $\sim 640,000$ tons as of 2016, and $90 \%$ of these mandarins are processed into juices and beverages. An enormous amount of peel is generated as a by-product during processing (KOSIS, 2016). Dried mandarin peel can be used as a medical herb. Pre-treated dried mandarin peel can be used as a feed (Jang et al., 2004). However, storage of this dried peel is a problem because mandarin is cultivated every two months in a year. Thus, a significant amount of mandarin peel is dumped into the ocean, thereby causing environmental pollution.

Sawdust, a by-product from wood processing, is used herein. Since sawdust has a high water uptake rate, it is mainly used for manure handling in livestock farms. Sawdust compost is used for producing by-products and for feed.

${ }^{1}$ Date Received October 10, 2018, Date Accepted December 27, 2018

2 Department of Wood Science \& Technology, Chonbuk National University, Chonju 54896, Republic of Korea

$\dagger$ Corresponding author: Seung-Won Oh (e-mail: ohsw@jbnu.ac.kr, ORCID: 0000-0002-6601-9789) 
Change of Surface Temperature and Far-infrared Emissivity in Ceramics Manufactured from a Board Mixed with Sawdust and Mandarin Peel

Although the quantity of sawdust generated depends on the log thickness and lumber dimension, sawdust with a volume ratio of $\sim 10 \%$ can be generally obtained. According to the Statistical Yearbook of Forestry 2017, $979,527 \mathrm{~m}^{3}$ and 53.9 billion won worth of sawdust was produced in 2016 and consumer price was 55,000 won $/ \mathrm{m}^{3}$, which is only $1 / 5$ of the wholesale price for lumber. Therefore, if sawdust produced from thinning logs and forest wood waste is used effectively, it will significantly contribute to the activation of domestic forestry and wood processing industry.

In this study, woodceramics are manufactured using new porous carbon material developed by Okabe and Saito (1995), which was obtained by carbonizing in vacuum after impregnating with phenol formaldehyde resin. It is light and hard and has excellent corrosion resistance, durability, and thermal conductivity. It has several characteristics, including electromagnetic wave shielding effect and far-infrared radiation, and is cheaper than other C-C compounds. Thus, this new material will be used as raw materials for producing electromagnetic products, friction materials, and automobile accessories in the future (Okabe and Saito, 1995a, 1995b; Okabe et al., 1995a, 1995b).

Oh (2001, 2002, 2003) measured the physical properties of woodceramics developed from sawdust board made of thinned logs, and Oh (2002) and Oh \& Byeon $(2002,2003)$ fabricated woodceramics under various conditions using medium density fiberboard (MDF) and determined its properties. By re-carbonizing the woodceramics made from sawdust board, Oh \& Hwang (2009) prepared high-density woodceramics and determined its basicproperties. Byeon et al. (2010) investigated the effect of carbonization temperature and resin impregnation rate on the properties of the woodceramics made from Broussonetia kazinoki Sieb. Oh et al. (2014) measured the basic properties of the woodceramics made from miscanthus sinensis var. purpurascens particles, and Won et al. (2014) studied the development of new material using ligneous materials by evaluating the nondestructive bending strength of miscanthus sinensis var. purpurascens woodceramics at carbonization temperatures.

Hwang \& Oh (2017) determined the physical properties of woodceramics made from sawdust and mandarin peel. Oh et al., (2018) manufactured carbonized board at carbonization temperature using ash tree board, PB, MDF, and plywood and examined the possibility of using the carbonized board as a heating plate. Various manufacturing methods and applications have been studied (Hokkirigawa et al., 1996a, 1996b; Hirose et al., 2002; Iizuka et al., 1999; Xian et al., 2002; Zhao et al., 2002; Oh and Park, 2010; Oh and Piao, 2004; Hwang and Oh. 2017). This study examined the possibility of using carbonized board as a planar heating element by evaluating the changes in surface temperature of the composite woodceramics and the far-infrared radiation properties based on the manufacturing conditions. These parameters were evaluated for boards prepared using different density and mixing ratios of mandarin peel and sawdust. These boards were impregnated with resin and ceramicized via carbonization at $\geq 600^{\circ} \mathrm{C}$.

\section{MATERIALS and METHODS}

\subsection{Testing materials}

\subsubsection{Sawdust}

Sawdust obtained from the thinning of Larix kaemferi C. was purchased from sawmill. For the uniformity of the samples during the manufacture of the board, theparticle size of 18 mesh was selected and the water content was adjusted to $\leq 6 \%$.

\subsubsection{Mandarin peel}

Mandarin peel was purchased from Jeju Island and dried under shade. To increase the bonding strength 
during board manufacturing, a particle size of 18 mesh was obtained by crushing the peel using a pulverizer and water content was adjusted to $\leq 5 \%$.

\subsubsection{Resin}

To prepare a board mixed with sawdust and mandarin peel, powder phenolic resin (KNB-100PL, manufactured by Kolon Chemical Industry Co., Ltd.) was used. The amount of resin added was $10 \%$ (weight ratio) of the mixed amount of sawdust and mandarin peel. A liquid phenolic resin (KPD-L777, KOLON CHEMICAL Co., Ltd.) was used for impregnation to produce woodceramics. Table 1 shows the properties of each resin.

Table 1. Characteristics of phenol-formaldehyde resin for the test

\begin{tabular}{c|c|c}
\hline Resin types & $\begin{array}{c}\text { Powder resin } \\
\text { (Novolak type) }\end{array}$ & $\begin{array}{c}\text { Liquid resin } \\
\text { (Resol type) }\end{array}$ \\
\hline \hline Solid content (\%) & 99 & $51 \sim 53$ \\
Melting point $\left({ }^{\circ} \mathrm{C}\right)$ & $80 \sim 95$ & - \\
Specific gravity & - & 1.06 \\
Gelation time (sec) & $80 \sim 120$ & $80 \sim 95$ \\
Plate flow (mm) & $30 \sim 35$ & - \\
Viscosity (cps) & - & $45 \sim 65$ \\
\hline
\end{tabular}

\subsection{Test method}

\subsubsection{Preparation of composite board}

To manufacture the board, uniformly selected sawdust and mandarin peel and powdered phenolic resin were fully mixed and placed in a stainlesss quare mold on a hot plate of a hot press. A board size of $26 \mathrm{~cm}$ in width $\times 26 \mathrm{~cm}$ in length $-1.4 \mathrm{~cm}$ in thickness was produced via hot press molding. To obtain a board of $0.6-\mathrm{g} / \mathrm{cm}^{3}$ density, mandarin peel was added in the ratios of $5 \%, 10 \%, 15 \%, 20 \%$, and $25 \%$.

When the mandarin peel addition ratio was $10 \%$, a board with a density of $0.4,0.5,0.6$, and $0.7 \mathrm{~g} / \mathrm{cm}^{3}$ was manufactured. A total of 10 boards of each density was manufactured at a hot pressing temperature of $190^{\circ} \mathrm{C}$, pressure of $40 \mathrm{kgf} / \mathrm{cm}^{2} \rightarrow 30 \mathrm{kgf} / \mathrm{cm}^{2} \rightarrow 20$ $\mathrm{kgf} / \mathrm{cm}^{2}$ (three-stage pressurization), and pressing time was $6 \mathrm{~min} \rightarrow 5 \mathrm{~min} \rightarrow 4$ min (three-step pressing time). To maintain a constant board thickness during hot pressing, a thickbar was used. A teflon plate was used to prevent the adhesion of the upper and lower surfaces of the board due to heat from the hot plate.

\subsubsection{Impregnation of composite board}

The size of the manufactured board was $1.4 \times 12$ $\times 12 \mathrm{~cm}^{3}$, and its density was calculated. In addition, a specimen with a target density of $\pm 0.03 \mathrm{~g} / \mathrm{cm}^{3}$ was selected for each condition to keep the test conditions constant.

The prepared specimen was placed in an impregnation tank containing liquid phenolic resin. Then, decompression (1 atmosphere) and ultrasonic treatment (frequency: $28 \mathrm{kHz}$, output: $564 \mathrm{~W}$ ) were performed for $20 \mathrm{~min}$.

The specimen was subjected to these treatments at a normalpressure for $20 \mathrm{~min}$. This process was repeated three times, and the impregnation rate was controlled by adjusting the repetition times. A decompression ultrasonic impregnation device used for impregnation comprises an impregnation tank, an ultrasonic vibration part, an ultrasonic oscillation part, and a vacuum pump. After the impregnated specimen was dried under shade for $8 \mathrm{~h}$, it was placed in a drier and cured continuously at $60^{\circ} \mathrm{C}$ for $8 \mathrm{~h}$ and at $130^{\circ} \mathrm{C}$ for $8 \mathrm{~h}$. Then, the physical properties of the board before and after impregnation were measured.

\subsubsection{Manufacturing of woodceramics}

Woodceramics were prepared by selecting boards with a resin impregnation rate of $60 \pm 3 \%$ among boards with a mandarin peel addition ratio of $5 \%, 10 \%, 15 \%$, 
$20 \%$, and $25 \%$ and board with a resin impregnation rate of $40 \pm 3 \%, 50 \pm 3 \%, 60 \pm 3 \%$, and $70 \pm 3 \%$ among the impregnated boards with a mandarin peel addition ratio of $10 \%$ using a vacuum furnace. These boards were carbonized at $800^{\circ} \mathrm{C}$. In addition, woodceramics were prepared by selecting specimens with resin impregnation rate of $50 \pm 3 \%$ among the impregnated boards with density of $0.6 \mathrm{~g} / \mathrm{cm}^{3}$ and a mandarin peel addition ratio of $10 \%$ and carbonizing at $600^{\circ} \mathrm{C}, 800^{\circ} \mathrm{C}, 1000^{\circ} \mathrm{C}$, and $1200^{\circ} \mathrm{C}$, respectively. During this time, the temperature was raised from the room temperature to $4^{\circ} \mathrm{C} / \mathrm{min}$; after maintaining at the set temperature for $2 \mathrm{~h}$, cold water was circulated around the carbonization furnace to cool it.

\subsubsection{Measurement of properties}

\subsubsection{Calculation of impregnation rate}

The resin impregnation rate of the impregnated material was calculated from Equation (1) as the percentage of resin injected for the oven-dry weight of the composite board.

$$
\begin{aligned}
& \text { Resin impregnation rate }(\%) \\
& =(\mathrm{W} 1-\mathrm{Wn}) / \mathrm{Wn} \times 100,
\end{aligned}
$$

where

W1: the oven-dry weight of board after resin impregnation (g)

Wn: the oven-dry weight of board before resin impregnation (g)

2.2.4.2. Measurement of the surface temperature of woodceramics

To measure the surface temperature of the woodceramics, the surface temperature of the heater was increased. A temperature sensor was attached at the center of the heater after connecting the silicon rubber heater to the electric voltage regulator at the set temperature. The variation in temperature was measured by placing the woodceramics on the heated silicon rubber heater and attaching the temperature sensor to the four spots of the surface using a paper tape. The surface temperature of the silicon rubber heater was set as $60^{\circ} \mathrm{C}$ and the woodceramics was placed on it. The variation in the surface temperature of the ceramics was measured for $30 \mathrm{~min}$ at 3 min intervals. Then, the heater was turned off, after which the surface temperature of the ceramic surface and heater was measured for $30 \mathrm{~min}$ at $3 \mathrm{~min}$ intervals to determine the heat retention of woodceramics made from the manufactured board.

\subsubsection{Far-infrared radiation}

To investigate the far-infrared characteristics of woodceramics, a specimen of $30 \times 30 \times 2 \mathrm{~mm}^{3}$ was prepared and used as a test material. Far-infrared spectral emissivity was measured at $50^{\circ} \mathrm{C}$ using an FT-IR spectrometer (MIDAC, Corporation).

\section{RESULTS and DISCUSSION}

\subsection{Surface temperature change of mixed woodceramics}

To investigate the validity of the manufactured woodceramics as a planar heating element, the variations in surface temperature of the woodceramics were measured; the surface temperature of silicon rubber heater was maintained at $60^{\circ} \mathrm{C}$. The results are shown in Figs. 1-6. Woodceramics' surface temperature increases with time (Figs. 1-3). As shown in Fig. 1, surface temperature rapidly increases depending on the resin impregnation rate for $12 \mathrm{~min}$ and become gradual thereafter. Ceramic has a fast heat transfer rate in the beginning. After $30 \mathrm{~min}$, the surface temperature was $40.5^{\circ} \mathrm{C}, 41.7^{\circ} \mathrm{C}, 40.6^{\circ} \mathrm{C}$, and $41.3^{\circ} \mathrm{C}$ when the resin impregnation rate was $40 \%, 50 \%, 60 \%$, and $70 \%$, respectively, thereby showing similar values regardless 


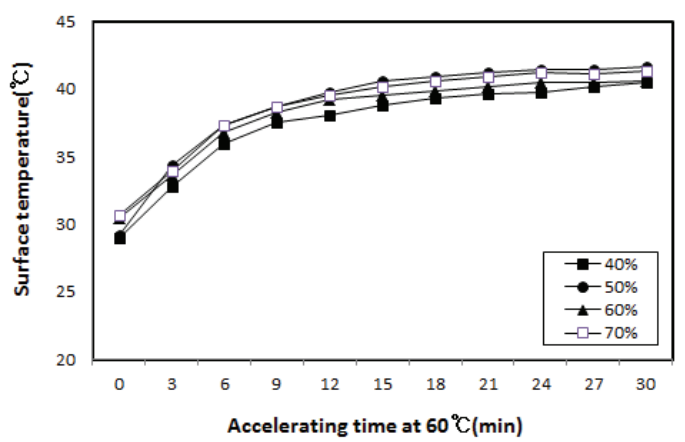

Fig. 1. Surface temperature for percentage of resin impregnation as a function of heating time.

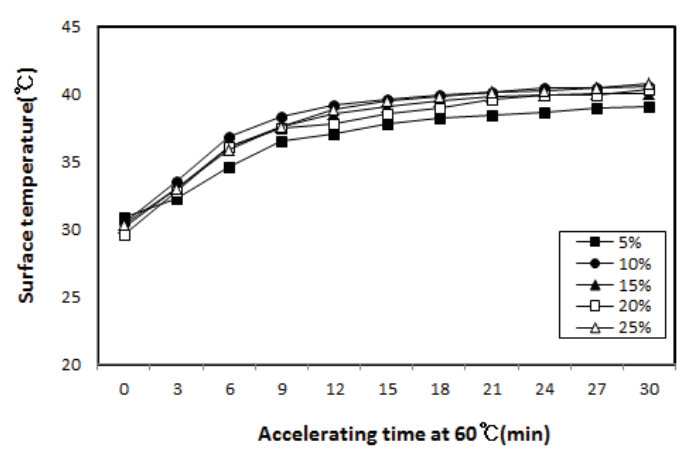

Fig. 3. Surface temperature for mandarin peels addition as a function of heating time.

of the impregnation rate. This indicates that there is no significant difference in the thermal conductivity of the specimens in accordance with the resin impregnation rate after carbonization.

As shown in Fig. 2, the surface temperature of woodceramics rapidly increased as the carbonization temperature increased up to $9 \mathrm{~min}$ and increased slowly afterwards. At $30 \mathrm{~min}$ from the beginning of the experiment, specimens with carbonization temperature of $600^{\circ} \mathrm{C}, 800^{\circ} \mathrm{C}$, and $1200^{\circ} \mathrm{C}$ had a surface temperature of $38.9^{\circ} \mathrm{C}, 41.7^{\circ} \mathrm{C}$, and $42.5^{\circ} \mathrm{C}$, respectively. At the carbonization temperature of $600^{\circ} \mathrm{C}$ and $1200^{\circ} \mathrm{C}$, the surface temperature of the specimen was the lowest and highest, respectively.

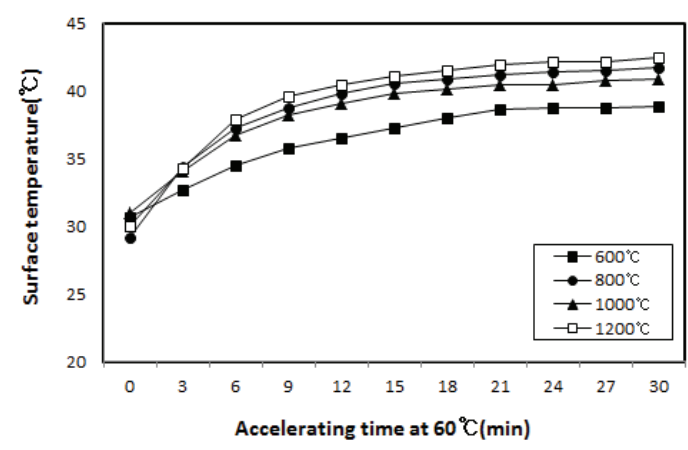

Fig. 2. Surface temperature for carboonization temperature as a function of heating time.

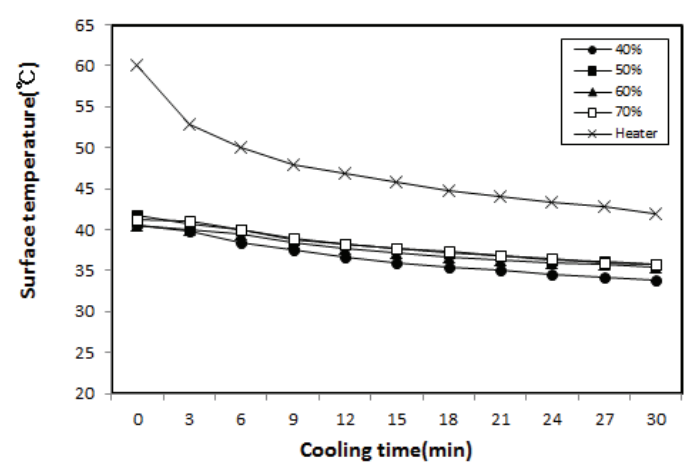

Fig. 4. Relationship between cooling and descent temperature of surface of ceramics with resin impregnation ratio.

As shown in Fig. 3, in case of mixed woodceramics for which specimen with a resin impregnation rate of $60 \%$ was carbonized at a carbonization temperature of $800^{\circ} \mathrm{C}$, change in surface temperature of woodceramics according to the mixing ratio of mandarin peel showed a tendency to rise rapidly until the elapsed time of $9 \mathrm{~min}$ and gradually increased thereafter. When the addition ratio was $5 \%, 10 \%, 15 \%, 20 \%, 25 \%$, the surface temperature of the woodceramics at the elapsed time of 30 min was $39.1^{\circ} \mathrm{C}, 40.6^{\circ} \mathrm{C}, 40.1^{\circ} \mathrm{C}, 40.4^{\circ} \mathrm{C}$, and $40.8^{\circ} \mathrm{C}$, respectively. All five specimens showed similar values, indicating that the mixing ratio of mandarin peel does not influence the thermal conductivity after carbonization. Conversely, after measuring the increase 
Change of Surface Temperature and Far-infrared Emissivity in Ceramics Manufactured from a Board Mixed with Sawdust and Mandarin Peel

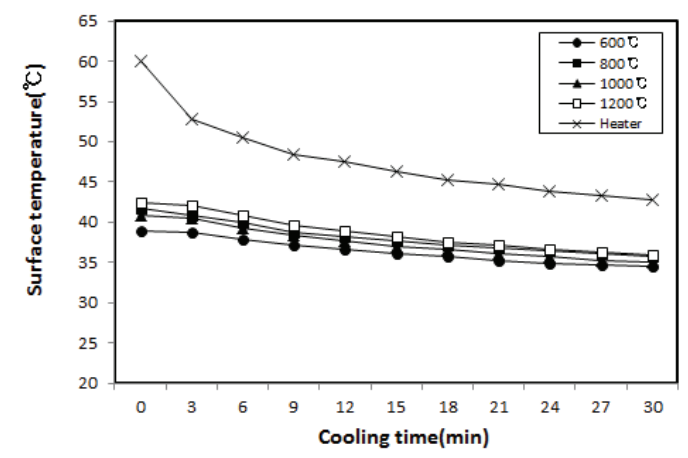

Fig. 5. Relationship between cooling and descent temperature of surface of ceramics with carbonizing temperature.

in surface temperature, the power of the silicone rubber heater was turned off to lower the surface temperatures of the heater and the woodceramics. The decrease in surface temperature of the heater was measured for 30 min at 3 min intervals; results are shown in Figs. 4-6.

As shown in Fig. 4, a decrease in surface temperature of the woodceramics according to the resin impregnation rate was observed as the surface temperature of the heater decreased from $60^{\circ} \mathrm{C}$ to $42^{\circ} \mathrm{Cfor} 30 \mathrm{~min}$. The surface temperature decreased from $40.5^{\circ} \mathrm{C}$ to $33.8^{\circ} \mathrm{C}$ for specimen with a resin impregnation rate of $40 \%$ and from $40.6^{\circ} \mathrm{C}$ to $35.4^{\circ} \mathrm{C}$ for specimen with a resin impregnation rate of $60 \%$. It decreased from $41.3^{\circ} \mathrm{C}$ to $35.7^{\circ} \mathrm{C}$ when with the resin impregnation rate was $70 \%$. Accordingly, the surface temperature of woodceramics decreased gradually after a point of time. As shown in Fig. 5, the surface temperature of the woodceramics decreased as the surface temperature of the heater decreased from $60^{\circ} \mathrm{C}$ to $42.8^{\circ} \mathrm{C}$ for $30 \mathrm{~min}$. The surface temperature decreased from $38.9^{\circ} \mathrm{C}$ to $34.5^{\circ} \mathrm{C}$ for the specimen carbonized at $600^{\circ} \mathrm{C}$ and from $40.9^{\circ} \mathrm{C}$ to $35.0^{\circ} \mathrm{C}$ for the specimen carbonized at $1000^{\circ} \mathrm{C}$. It decreased from $42.5^{\circ} \mathrm{C}$ to $36.0^{\circ} \mathrm{C}$ for the specimen carbonized at $1200^{\circ} \mathrm{C}$, continuing to decrease gradually with time. The difference between the initial temperature of the specimen prepared at carbonization

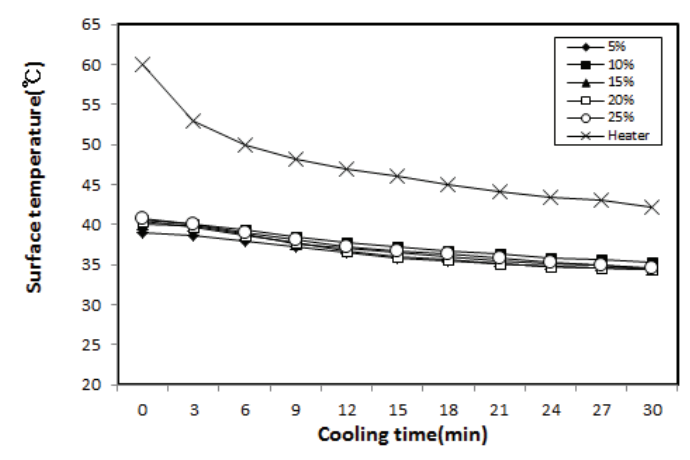

Fig. 6. Relationship between cooling and descent temperature of surface of ceramics with mandarin peels addition ratio.

temperature of $1200^{\circ} \mathrm{C}$ and the temperature after 30 min was large $\left(6.5^{\circ} \mathrm{C}\right)$, and the surface temperature of the specimen at $600^{\circ} \mathrm{C}$ was relatively low $\left(4.4^{\circ} \mathrm{C}\right)$. Regarding the decrease of surface temperature of the woodceramics, a lower carbonization temperature was associated with higher degree of heat retention. As shown in Fig. 6, the surface temperature of the mixed woodceramics according to the mixing ratio of mandarin peel decreased as the surface temperature of the heater decreased from $60^{\circ} \mathrm{C}$ to $42.2^{\circ} \mathrm{C}$. The surface temperature decreased from $39.1^{\circ} \mathrm{C}$ to $34.4^{\circ} \mathrm{C}$ for the specimen with mandarin peel addition ratio of $5 \%$ and from $40.1^{\circ} \mathrm{C}$ to $34.4^{\circ} \mathrm{C}$ for the specimen with mandarin peel addition ratio of $15 \%$. It decreased from $40.8^{\circ} \mathrm{C}$ to $34.6^{\circ} \mathrm{C}$ for the specimen with mandarin peel addition ratio of $25 \%$.

The higher the addition ratio, the rapidly the ceramic surface temperature decreases but the difference is insufficient. Thus, woodceramics manufactured with the resin impregnation ratio of $\geq 70 \%$ and mandarin peel addition ratio is $5 \%$ at $1200^{\circ} \mathrm{C}$ can be used as a raw material. Further, since the manufactured woodceramics retains heat for a long time, it can be used as a material for a planar heating element. However, as the change in surface temperature of woodceramics seems to be most closely related to the density of the specimen, parameters, such as resin impregnation rate, carbonization temperature, 
temperature rise, material properties, and electrical properties, required for woodceramic manufacturing must be studied in the future.

\subsection{Far-infrared radiation characteristics of mixed woodceramics}

Far-infrared emissivity and infrared-radiation emission power were measured for mixed woodceramics with a resin impregnation rate of $60 \%$ carbonated at $800^{\circ} \mathrm{C}$. Results are shown in Figs. 7 and 8. Total emissivity compared to ideal blackbody in the 5-20- $\mu \mathrm{m}$ wavelength region of the woodceramics was 0.929, 0.927, 0.929,

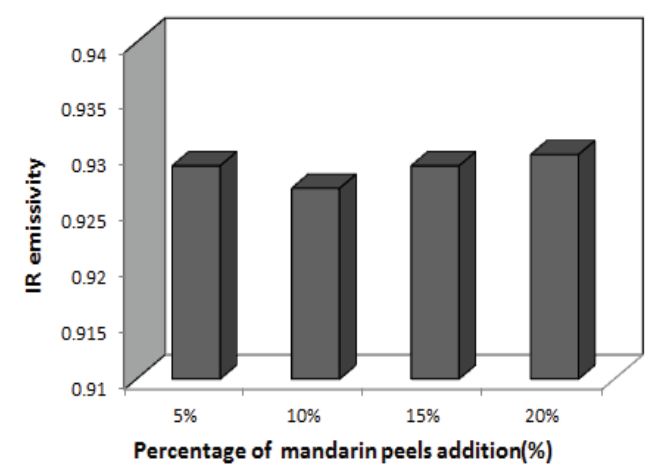

Fig. 7. Relationship between percentage of mandarin peels addition and IR emissivity.

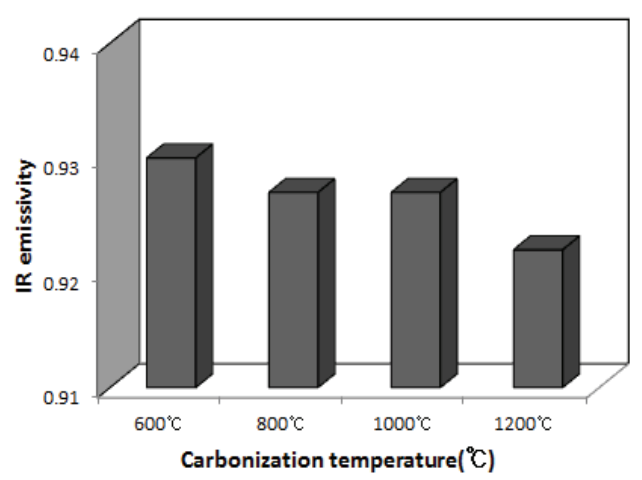

Fig. 9. Relationship between carbonization temperature and IR emissivity. and 0.930 when the mandarin peel addition ratio was $5 \%, 10 \%, 15 \%$, and $20 \%$, respectively. The far-infrared emissivity by mandarin peel addition ratio increased slightly with increasing mandarin peel addition ratio. IR emission power was $375,373,374$, and $375 \mathrm{~W} / \mathrm{m}^{2}$ when the mandarin peel addition ratio was $5 \%, 10 \%$, $15 \%$, and $20 \%$, respectively. Thus, the IR emission power was the highest when the mandarin peel addition ratio was $5 \%$ but there was no significant difference when compared to other specimens.

Moreover, far-infrared emissivity and IR emission in accordance with the carbonization temperature of the mixed woodceramics were measured after carbonizing

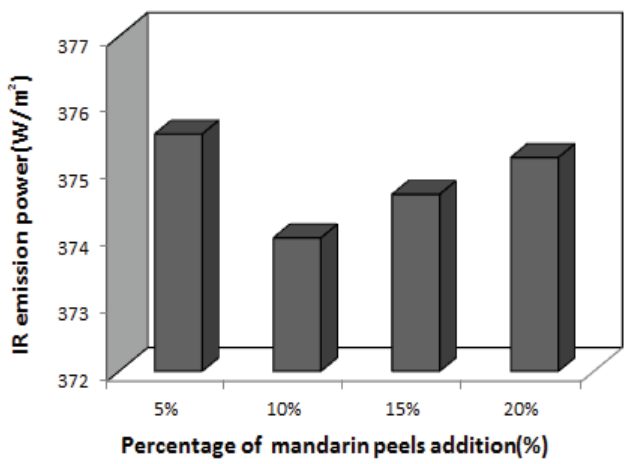

Fig. 8. Relationship between percentage of mandarin peels addition and IR emission power.

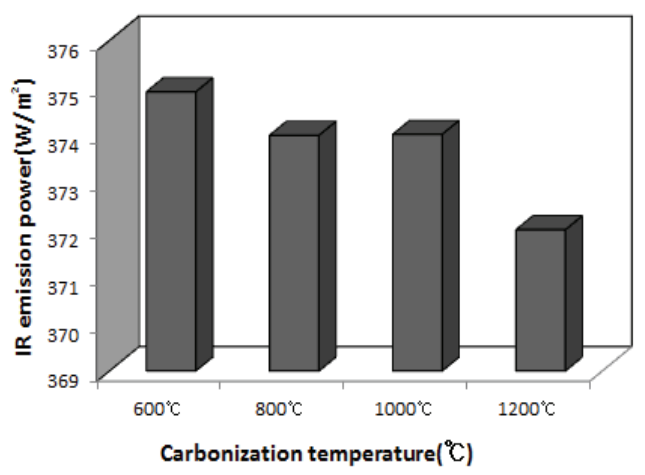

Fig. 10. Relationship between carbonization temperature and IR emission power. 
the board with a resin impregnation rate of $60 \%$ and a mandarin peel addition ratio of $10 \%$. Results are shown in Figs. 9 and 10. The far-infrared emissivity was 0.930 and 0.927 when the carbonization temperature was $600^{\circ} \mathrm{C}$ and $800^{\circ} \mathrm{C}$, respectively. The far-infrared emissivity was 0.927 and 0.922 when the carbonization temperature was $1000^{\circ} \mathrm{C}$ and $1200^{\circ} \mathrm{C}$, respectively. This indicates that the far-infrared emissivity decreased as the carbonization temperature increased. IR emission power was 374 and $373 \mathrm{~W} / \mathrm{m}^{2}$ when the carbonization temperature was $600^{\circ} \mathrm{C}$ and $800^{\circ} \mathrm{C}$. IR emission power was 374 and $371 \mathrm{~W} / \mathrm{m}^{2}$ when the carbonization temperature was $1000^{\circ} \mathrm{C}$ and $1200^{\circ} \mathrm{C}$, respectively. IR emission power tended to decrease as the carbonization temperature increased. Oh (2016) reported that higher carbonization temperature is associated with decreasing emissivity in far-infrared emissivity measurement of woodceramics made with sawdust and rice husk. This far-infrared emissivity was higher than silica sand (0.60 $\sim 0.80$ ), elvan (0.90), and $\mathrm{SiO}_{2}(0.83)$ and similar to charcoal (0.93), graphite (0.93), and ceramic-coated board (0.924). In particular, woodceramics made with sawdust and rice husk showed higher value than the measured far-infrared emissivity of woodceramics made from thinned logs (Oh and Byeon,2006).

\section{CONCLUSION}

Using sawdust and mandarin peel, a mixed woodceramics was prepared using various resin impregnation rates, carbonization temperatures, and mandarin peel addition ratios. The surface temperature and far-infrared radiation characteristics of the mixed woodceramics were determined and the following conclusions were deduced:

1. As the surface temperature of the mixed woodceramics rapidly increased until the elapsed time of $10 \mathrm{~min}$, the rate of temperature rapidly increased at the initial time of heat transfer. At the elapsed time of $30 \mathrm{~min}$, the surface temperature increased as the carbonization temperature increased and the mandarin peel addition ratio had no significant effect on the surface temperature variations.

2. The far-infrared emissivity did not have a certain trend depending on mandarin peel addition ratio and decreased as carbonization temperature increased. IR emission power also showed a similar tendency as the far-infrared emissivity.

\section{REFERENCES}

Byeon, H.S., Hwang, K.K., Lee, D.H., Hwang, J.W., Oh, S.W. 2010. Properties of woodceramics made from broussonetia kazinoki sievb: Effect of carbonization temperature. Journal of Agriculture \& Life Science 44(4): 21-27.

Hirose, T., Fujino, T., Fan, T., Endo, H., Okabe, T., Yoshimura, M. 2002. Effect of carbonization temperature on the structural changes of woodceramics impregnated with liguefied wood. Carbon 40: 761-765.

Hokkirigawa, K., Okabe, T., Saito, K. 1996a. Wear properties of new porous carbon materials: woodceramics. Journal of Porous Materials 2: 229-235.

Hokkirigawa, K., Okabe, T., Saito, K. 1996b. Friction properties of new porous carbon materials: woodceramics. Journal of Porous Materials 2: 237-243.

Hwang, J.W., Oh, S.W. 2017. Physical properties of ceramics manufactured from a boards mixed with sawdust and mandarin peels. Journal of the Korean Wood Science and Technology 45(3): 335-342. Hwang, J.W., Oh, S.W. 2017. Physical and Mechanical Properties of Board Made from Carbonized Rice 
Husk. Journal of the Korean Wood Science and Technology 45(1): 62-71.

Jang, S.Y., Choi, H.K., Ha, N.Y., Kim, O.M., Jeong, Y.J. 2004. Study on the antimicrobial effects of citrus peel by different extract methods. Korean Journal of Food Preservation 11(3): 319-324.

Korea Forest service. 2017. Statistical yearbook of forestry. 11-1400000-000001-10.

Korean statistical information service. 2016. Agriculture, forestry and fishery.

Iizuka, H., Masimi, F., Okabe, T., Saito, K. 1999. Mechanical properties of woodceramics: A porous carbon material. Journal of Porous Materials 6: 175-184.

Oh, S.W. 2001. Properties of woodceramics made from thinned logs of Cryptomeria japonica D. Don-Effect of steam injection and its time-. Journal of the Korean Wood Science and Technology 29(2): 69-75.

Oh, S.W. 2002. Change of Surface Temperature in woodceramics made from MDF(I): Effect of density and burning temperature. Journal of Korea Forestry Energy 2(1): 1-6.

Oh, S.W. 2002. Properties of sawdust board made from thinned logs(I): Effect of pressure and press Time. Journal of Korea Forestry Energy 21(2): 10-16.

Oh, S.W. 2003. Physical and mechanical properties of sawdust board made of thinning $\operatorname{logs}(\Pi)$ : The effect of density and additive quantity of powder phenolic resin. Journal of the Korean Wood Science and Technology 31(3): 17-23.

Oh, S.W. 2016. Electrical properties and far-infrared ray emission of ceramics manufactured with sawdust and rice husk. Journal of the Korean Wood Science and Technology 44(1): 106-112.

Oh, S.W., Byeon, H.S. 2002. Properties of woodceramics made from MDF. Journal of the Korean Wood Science and Technology 30(2): 115-120.
Oh, S.W., Byeon, H.S. 2003. Change of Surface temperature in woodceramics made from $\operatorname{MDF}(\Pi)$ : Effect of impregnation rate and burning temperature. Journal of the Korean Wood Science and Technology 31(1): 41-45.

Oh, S.W., Hwang, J.W. 2009. Properties and manufacture of high density woodceramics by recarbonization: Effect of carbonization temperature. Journal of the Korean Wood Science and Technology 37(6): 517-523.

Oh, S.W., Hwang, J.W., Park, S.B. 2018. Effect of carbonization temperature on the surface temperature of carbonized board. Journal of the Korean Wood Science and Technology 46(1): 60-66.

Oh, S.W., Byeon, H.S. 2006. Far-infrared ray emission and electrical properties of woodceramics manufactured with thinned logs. Forest Products Journal 56(7/8): 29-32.

Oh, S.W., Piao, J.J. 2004. Properties of woodceramics made from thinned $\operatorname{logs}(\mathrm{I})$ : Effect of resin impregnation rate and burning temperature. Journal of the Korean Wood Science and Technology 32(1): 73-79.

Oh, S.W., Park, H.J. 2010. A change in surface temperature of ceramics made from board mixed with sawdust and rice husk: Effect of resin impregnation rate and carbonization temperature. Journal of the Korean Wood Science and Technology 38(1): 43-48.

Oh, S.W., Park, H.J., Hwang, J.W. 2014. Characteristics of Ceramics from Miscanthus sinensis var. purpurascens Particle Board. Journal of the Korean Wood Science and Technology 42(3): 251-257.

Okabe, J., Saito, K. 1995a. Development of woodceramics. Transactions of the Material Research Society of Japan 18: 681-684.

Okabe, T. Saito, K. 1995b. The examination of the manufacturing method of woodceramics(I): Structural changes affected by burning temperature. 
International Ecomaterial Conference, Xian, China pp. 1-4.

Okabe, T., Saito, K., Togawa, H., Kumagai, Y. 1995a.

Electromagnetic shielding characteristic of porous carbon material "woodceramics". International Ecomaterial Conference, Xian, China pp. 9-12.

Okabe, T., Saito, K., Togawa, H., Kumagai, Y. 1995b. Development of porous carbon material "woodceramics": Electromagnetic shielding characteristics. Journal of the Society of Materials Science Japan 44(498): 288-291.

Won, K.R., Oh, S.W., Byeon, H.S. 2014. Nondestructive Bending Strength Evaluation of Miscanthus sinensis var. purpurascens Ceramics Made from Different Carbonizing Temperatures. Journal of the Korean Wood Science and Technology 42(6): 723-731.

Xian, X.Q., Zhang, D., Fan, T.X., Sakata, T., Mori, H., Okabe, T., Hirose, T. 2002. The fabrication of composites with interpentrating networks based on woodceramics. Materials Letters 56: 102-107. Zhao, B.Y., Hirose, T., Okabe, T., Zhang, D., Fan, T.X., Hu, K.A. 2002. Woodceramics prepared from wood powder/phenolated wood composite. Journal of Porous Materials 9: 195-201. 


\title{
APPENDIX
}

\author{
(Korean Version)
}

\section{톱밥·귤박 혼합보드로 제조한 세라믹의 표면온도 변화 및 원적외선방사 특성}

초록 : 본 연구는 톱밥과 농업부산물인 귤박을 이용하여 보드를 제조하고 세라믹화 하여 표면온도 및 원적외선 방사특성을 조사하였다. 세라믹의 표면온도는 경과시간 10 분까지는 급속히 상승하였고, 30 분 후에는 탄화온도가 높을수록 높았고, 귤박 혼합율별로는 별 영향이 없었다. 원적외선 방사율은 귤박 혼합율에 따라 일정한 경향이 없었고, 탄화온도가 증가할수록 낮은 값을 보였다.

\section{1. 서 론}

목재자원 보유국의 자국 산업보호를 위한 정책으로 인해 목재자원의 부족현상이 계속될 것으로 보이며, 국내 목재가격 도 매년 상승하고 있어서 폐목재자원, 건축폐기물 및 간벌재등 이용 가능한 목질자원을 활용한 친환경 재료의 개발이 시급한 실정이다.

이러한 현실을 극복하기 위하여 목질을 비롯한 섬유자원의 대체효과를 가질 수 있는 국내 목재수급체계가 확립되어야 하고, 기타 농업 부산물을 이용한 신소재자원의 개발이 필요한 실정이다. 국내산 감귤의 연간 생산량은 2016년도 기준 약 640,000 톤 이며, 이들 중 $90 \%$ 는 쥬스와 음료로 가공되는데 가공 중 엄청난 양의 과피 등이 부산물로 나온다(KOSIS, 2016). 감귤박의 처리는 이미 오래 전부터 알려진 데로 건조시킬 경우 그 자체로도 진피라는 한약재로 쓰일 뿐 아니라 별도의 전처리 없이도 사료로서 유용하게 활용될 수 있는 것으로 연구 되었다(Jang et al., 2004). 하지만 이러한 상황에서도 감귤박이 년 중 2개월이라 는 짧은 기간 동안 집중적으로 발생되기 때문에 저장 문제가 해결되지 않아 지역의 현안 문제로 대두되고 있으며, 집중 발생 시에는 처분이 어려워 상당량을 해양투기 하고 있어 환경오염 문제가 심각하다.

또한 본 연구에서 재료로 사용한 톱밥은 목재의 제재과정에서 발생되는 부산물로서 수분흡수율이 매우 높아 주로 가축농가에 서 분뇨처리용으로 사용되고 있으며, 일부는 톱밥을 부숙시켜 부산물 제조 및 사료용으로 사용되고 있다.

원목 가공과정에서 발생되는 제재 부산물인 톱밥은 원목의 굵기와 제재목의 치수에 따라 다르지만 대체로 용적비 $10 \%$ 내외의 톱밥이 발생한다. 톱밥은 2017년 임업통계연보에 따르면 2016년에 979,527m³, 539억원 정도 생산되었고, 소비가격은 55,000 원 $/ \mathrm{m}^{3}$ 으로 수종에 따라 차이가 있지만 제재목 도매가격의 $1 / 5$ 에 지나지 않는다. 그러므로 간벌재 및 임지 폐목재로 생산되는 톱밥을 효과적이고 고부가가치적으로 이용한다면 국내 임업 및 목재 가공산업의 활성화에 크게 기여할 것으로 생각된다.

한편 본 연구에서 제조하고자하는 목재세라믹은 Okabe와 Saito(1995)가 목질재료에 페놀수지를 함침한 후 진공상태에서 탄화시켜 만든 새로운 다공질 탄소재료이다. 이는 목재가 가지고 있는 다공성의 성질을 지니고 있으면서, 가볍고 단단하며, 내부식성, 내구성 및 열전도성이 우수하고 전자파 차폐 효과와 원적외선 방사 등의 특성이 있으며, 가격이 다른 C-C화합물보다 저렴하여 전자기 제품의 원료, 마찰재료 및 자동차 부속재료등 앞으로 공업적으로 다양한 분야에서 이용이 기대되는 물질이다 (Okabe and Saito, 1995a, 1995b; Okabe et al., 1995a, 1995b). 또한 최근에는 Oh(2001, 2002, 2003)는 간벌재로 만든 톱밥보드를 이용하여 제조한 우드세라믹에 대한 물성을 측정하였고, Oh(2002)와 Oh \& Byeon(2002, 2003)은 MDF(Medium Density Fiberboard)를 이용하여 다양한 조건으로 우드세라믹을 제조하고 그 물성을 측정하였다. Oh \& Hwang(2009) 톱밥보 드로 제조한 우드세라믹을 재 탄화시켜 고밀도 우드세라믹을 제조하여 기초물성을 측정하였으며, Byeon et al.(2010)은 탄화온 도와 수지함침율이 닥나무 우드세라믹의 물성에 미치는 영향을 조사하였다. Oh et al.(2014)은 거대억새 파티클보드로 제조된 세라믹의 기초물성을 측정하였고, Won et al.(2014)은 거대억새 우드세라믹의 탄화온도별로 비파괴 휨강도 평가를 실시하여 목질재료를 이용한 신소재 개발에 대한 연구를 수행한 바 있고, Hwang \& Oh(2017)는 톱밥과 귤박을 이용하여 제조한 세라믹 의 물리적 성질을 측정하였다. Oh et al.(2018)은 물푸레나무 판재, $\mathrm{PB}, \mathrm{MDF}$ 및 합판을 이용하여 탄화온별로 탄화보드를 제조하여 발열판으로 이용가능성을 검토하였다. 그 외 다양한 제조방법과 용도개발에 관한 연구가 수행되었다 (Hokkirigawa et al., 1996a, 1996b; Hirose et al., 2002; Iizuka et al., 1999; Xian et al., 2002; Zhao et al., 2002; Oh and Park, 2010; Oh and Piao, 2004; Hwang and Oh. 2017).

따라서 본 연구에서는 농업부산물인 감귤박과 제재과정에서 발생되는 톱밥을 이용하여 밀도와 혼합비를 달리하여 혼합보드 
를 제조하고 수지를 함침한 후 $600^{\circ} \mathrm{C}$ 이상의 고온으로 탄화하여 세라믹화한 후 제조조건에 따른 혼합세라믹의 표면온도변화 및 원적외선 방사특성을 조사함으로써 혼합세라믹을 면상발열체의 소재로 이용가능성을 검토하였다.

\section{2. 재료 및 방법}

\section{1. 공시재료}

\subsection{1 톱밥}

톱밥은 낙엽송(Larix kaemferi C.) 간벌재 제재 시 발생된 것을 시중 제재소에서 구입하여 사용하였으며, 보드 제조시 시료의 균일함을 위하여 입자의 크기를 18 mesh로 선별하고 함수율은 $6 \%$ 이하로 조절하였다.

\subsection{2. 귤박}

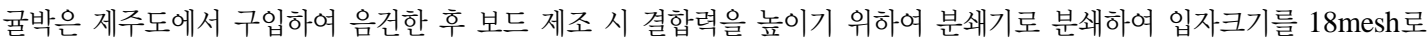
선별하고 함수율은 $5 \%$ 이하로 조절하여 사용하였다.

\subsection{3. 수지}

톱밥귤박 혼합보드 제조를 위하여 분말상 페놀수지(코오롱유화(주), KNB-100PL)를 사용하였으며, 수지첨가량은 톱밥·귤박 혼합량의 $10 \%$ (중량비)로 하였다. 세라믹 제조를 위한 함침에는 액상 페놀수지(코오롱유화(주), KPD-L777)를 사용하였으며 각 수지의 특성의 Table 1 과 같다.

\section{2. 시험방법}

\subsection{1. 혼합보드 제조}

보드를 제조하기 위하여 균일하게 선별된 톱밥과 귤박 및 분말상 페놀수지를 충분히 혼합하여 열압기의 열판위에 있는 스테인레스 정방형 몰드 속에 넣고 시료상부의 높이를 일정하게 조절한 후 열압 성형하여 가로 $26 \mathrm{~cm} \times$ 세로 $26 \mathrm{~cm} \times$ 두께 $1.4 \mathrm{~cm}$ 의 보드를 제조하였다. 보드의 제조 조건은 밀도 $0.6 \mathrm{~g} / \mathrm{cm}^{3}$ 일 때 귤박 혼합율 $5 \%, 10 \%, 15 \%, 20 \%, 25 \%$ 인 보드, 그리고 귤박혼합율 $10 \%$ 일 때 밀도 $0.4 \mathrm{~g} / \mathrm{cm}^{3}, 0.5 \mathrm{~g} / \mathrm{cm}^{3}, 0.6 \mathrm{~g} / \mathrm{cm}^{3}, 0.7 \mathrm{~g} / \mathrm{cm}^{3}$ 인 보드를 각각 10 장씩 제조 하였다. 이때 열압온도는 $190^{\circ} \mathrm{C}$, 가압압력은 $40 \mathrm{kgf} / \mathrm{cm}^{2} \rightarrow 30 \mathrm{kgf} / \mathrm{cm}^{2} \rightarrow 20 \mathrm{kgf} / \mathrm{cm}^{2}$ (3단 가압), 가압시간 6 분 $\rightarrow 5$ 분 $\rightarrow 4$ 분(3단 가압시간)으로 하였다. 열압과정에서 보드의 두께를 일정하게 하기 위하여 thickness bar를 사용하였으며, 열에 의한 보드의 상하면과 열판의 부착을 방지하기 위하여 테프론 판을 사용하였다.

\subsection{2. 혼합보드의 함침처리}

제조한 보드를 두께 $1.4 \mathrm{~cm}$ 그리고 단면의 크기를 가로 $12 \mathrm{~cm} \times$ 세로 $12 \mathrm{~cm}$ 의 크기로 재단한 다음 밀도를 계산하였다. 또한 시험조건을 일정하게 하기 위하여 조건별로 목표밀도 $\pm 0.03 \mathrm{~g} / \mathrm{cm}^{3}$ 인 시편을 선정하였다.

준비된 시편을 액상 페놀수지가 들어있는 함침탱크에 넣은 후 감압(1기압)과 초음파처리(주파수: $28 \mathrm{kHz}$, 출력: $564 \mathrm{~W}$ )를 20 분 동안 병행한 후 다시 상압에서 20 분 동안 방치하는 방법으로 3 반복하였고 반복시간을 조절하여 함침율을 조절하였다. 함침에 사용한 감압 초음파 함침장치는 함침탱크, 초음파진동부, 초음파 발진부, 진공펌프 등으로 구성되어 있다. 함침 후의 시편을 8 시간 음건한 후, 다시 건조기에 넣고 $60^{\circ} \mathrm{C}$ 에서 8 시간, $130^{\circ} \mathrm{C}$ 에서 8 시간 연속 건조 및 경화시킨 다음 함침 전·후의 물리적 특성을 측정하였다.

\subsection{3. 세라믹 제조}

귤박혼합율이 $5 \%, 10 \%, 15 \%, 20 \%, 25 \%$ 인 보드 중 수지함침율 $60 \pm 3 \%$ 인 보드와 귤박혼합율이 $10 \%$ 인 함침보드 중 수지함 침율이 $40 \pm 3 \%, 50 \pm 3 \%, 60 \pm 3 \%, 70 \pm 3 \%$ 인 보드를 선정하여 진공탄화로를 이용하여 $800^{\circ} \mathrm{C}$ 에서 탄화하여 세라믹을 제조하였 다. 또한 밀도가 $0.6 \mathrm{~g} / \mathrm{cm}$ 이고, 귤박혼합율이 $10 \%$ 인 함침보드 중 수지함침율이 $50 \pm 3 \%$ 시편을 선정하여 $600^{\circ} \mathrm{C}, 800^{\circ} \mathrm{C}, 1000^{\circ} \mathrm{C}$, $1200^{\circ} \mathrm{C}$ 로 각각 탄화하여 세라믹을 제조하였다. 이 때 실온에서 설정온도까지 $4^{\circ} \mathrm{C} / \mathrm{min}$ 으로 승온 하였으며, 설정온도에서 2 시간 유지한 후 탄화로 주위에 냉각수를 순환시켜 냉각시켰다. 


\subsection{4. 물성 측정}

2.2.4.1. 함침율 계산

함침재의 수지함침율은 혼합보드의 전건중량에 대하여 주입된 수지량을 백분율로 표시한 것으로 식 (1)로부터 구하였다.

$$
\text { 수지함침율 }(\%)=(\mathrm{W} 1-\mathrm{Wn}) / \mathrm{Wn} \times 100
$$

$$
\begin{gathered}
\text { 여기서, } \mathrm{W} 1 \text {; 수지함침 후의 보드 전건중량 }(\mathrm{g}) \\
\mathrm{Wn} \text {; 수지함침 전의 보드 전건중량 }(\mathrm{g})
\end{gathered}
$$

\subsubsection{2. 세라믹의 표면온도 측정}

혼합보드로 제조된 세라믹의 표면온도 변화를 측정하기 위하여 전기전압 조절장치에 실리콘러버 히터(Silicon rubber heater) 를 연결하고 목표온도를 설정한 후 온도센서를 히터의 중앙에 부착하여 온도를 올리면서 히터의 표면온도를 고정하였다. 가열된 실리콘 러버히터위에 세라믹을 올려놓고, 그 표면 4곳에 온도센서를 종이테이프로 부착하여 온도상승 및 하강시간을 측정하였다. 시간의 경과에 다른 세라믹의 표면온도 상승 및 하강변화는 실리콘러버 히터의 표면 온도를 $60^{\circ} \mathrm{C}$ 로 설정하고 그 위에 세라믹을 올려놓은 다음 3 분 간격으로 30 분 동안 세라믹의 표면온도 상승을 측정한 후 히터의 전원을 끄고 세라믹 표면 및 히터의 표면온도를 3 분 간격으로 30 분 동안 온도하강 변화를 측정하여 세라믹의 열유지 정도를 조사하였다.

\subsubsection{3. 원적외선 방사}

세라믹의 원적외선 특성을 조사하기 위하여 가로 $30 \mathrm{~mm} \times$ 세로 $30 \mathrm{~mm} \times$ 두께 $2 \mathrm{~mm}$ 의 시편을 제작하여 공시재료로 사용하였다. 원적외선 분광 방사율은 FT-IR Spectrometer(MIDAC, Corporation)를 이용하여 $50^{\circ} \mathrm{C}$ 에서 측정하였다.

\section{3. 결과 및 고찰}

\section{1. 혼합세라믹의 표면온도 변화}

톱밥과 귤박의 혼합보드로 제조된 세라믹을 면상발열체로 사용하기 위한 기초자료를 조사하기 위하여 실리콘러버 히터의 표면온도 $60^{\circ} \mathrm{C}$ 위에서 세라믹의 표면온도 상승과 하강을 측정한 결과를 Figs. 1 6에 나타내었다.

시간의 경과에 따른 세라믹의 표면온도 상승을 Figs. 1 3에 나타내었다. 수지함침율별 표면온도 상승은 Fig. 1과 같이 시간이 경과함에 따라 경과시간 12 분까지 빠르게 상승하다가 이후에는 완만히 상승하는 경향을 나타내어 세라믹은 초기에 열전달속도가 빠름을 알수 있다. 경과시간 30 분 후의 표면온도는 수지함침율 $40 \%, 50 \%, 60 \%, 70 \%$ 일 때 각각 $40.5^{\circ} \mathrm{C}, 41.7^{\circ} \mathrm{C}$, $40.6^{\circ} \mathrm{C}, 41.3^{\circ} \mathrm{C}$ 로 함침율에 관계없이 유사한 값을 나타내었다. 이는 시편들이 탄화 후 수지함침율에 따른 열전도도가 큰차이가 없다는 것을 알 수 있다.

탄화온도별 세라믹의 표면온도 상승은 Fig. 2와 같이 경과시간 9분까지 빠르게 상승하다가 이후에는 완만해 지는 경향을 보였다. 경과시간 30 분후의 세라믹의 표면온도를 보면, 탄화온도 $600^{\circ} \mathrm{C}, 800^{\circ} \mathrm{C}, 1200^{\circ} \mathrm{C}$ 시편은 각각 $38.9^{\circ} \mathrm{C}, 41.7^{\circ} \mathrm{C}, 42.5^{\circ} \mathrm{C}$ 로, $600^{\circ} \mathrm{C}$ 시편의 표면온도가 최소치를 나타내고 $1200^{\circ} \mathrm{C}$ 시편의 표면온도가 최대치를 나타냈다.

또한 귤박혼합율에 따른 세라믹의 표면온도의 변화는 Fig. 3과 같이 수지함침율 $60 \%$ 인 시편을 탄화온도 $800^{\circ} \mathrm{C}$ 로 탄화한 혼합세라믹의 경우 경과시간 9 분까지 빠르게 상승하다가 이후에는 완만해 지는 경향을 보였다. 경과시간 30 분후의 세라믹의 표면온도를 보면 첨가율 $5 \%, 10 \%, 15 \%, 20 \%, 25 \%$ 일 때 각각 $39.1^{\circ} \mathrm{C}, 40.6^{\circ} \mathrm{C}, 40.1^{\circ} \mathrm{C}, 40.4^{\circ} \mathrm{C}, 40.8^{\circ} \mathrm{C}$ 로 5 개의 시편 모두 비슷한 값을 나타내었다. 이는 귤박혼합율이 탄화 후 열전도도에 영향을 미치지 않는다는 것을 알 수 있다. 한편 표면온도 상승 측정 후 실리콘러버히터의 전원을 꺼서 히터의 표면온도를 하강시키면서 3분 간격으로 30 분 동안 우드세라믹의 표면온도 와 히터의 표면온도 하강을 측정하여 시간의 경과에 따른 우드세라믹의 열 유지 정도를 조사한 결과를 Figs. 4 6에 나타내었다.

수지함침율에 따른 우드세라믹의 표면온도 하강은 Fig. 4 에 나타낸 바와 같이 히터의 표면온도가 30 분 동안 $60^{\circ} \mathrm{C}$ 에서 $42^{\circ} \mathrm{C}$ 로 감소함에 따라 수지함침율 $40 \%$ 시편의 경우 $40.5^{\circ} \mathrm{C}$ 에서 33.8 로, $60 \%$ 시편은 $40.6^{\circ} \mathrm{C}$ 에서 $35.4^{\circ} \mathrm{C}$ 로, $70 \%$ 일 때 $41.3^{\circ} \mathrm{C}$ 에 서 $35.7^{\circ} \mathrm{C}$ 로 시간이 경과함에 따라 우드세라믹의 표면온도도 완만히 하강하였다. 탄화온도별 우드세라믹이 표면온도의 하강은 Fig. 5 와 같이 히터의 표면온도가 30 분 동안 $60^{\circ} \mathrm{C}$ 에서 $42.8^{\circ} \mathrm{C}$ 로 감소함에 따라 탄화온도 $600^{\circ} \mathrm{C}$ 시편은 $38.9^{\circ} \mathrm{C}$ 에서 $34.5^{\circ} \mathrm{C}$ 로, $1000^{\circ} \mathrm{C}$ 시편은 $40.9^{\circ} \mathrm{C}$ 에서 $35.0^{\circ} \mathrm{C}$ 로, $1200^{\circ} \mathrm{C}$ 에서 $42.5^{\circ} \mathrm{C}$ 에서 $36.0^{\circ} \mathrm{C}$ 로 시간이 경과함에 따라 완만하게 하강하였다. 한편 탄화온도 $1200^{\circ} \mathrm{C}$ 로 제조된 시편의 처음온도와 30 분 후의 온도차이가 $6.5^{\circ} \mathrm{C}$ 로 온도 변화가 컸으며, $600^{\circ} \mathrm{C}$ 시편은 $4.4^{\circ} \mathrm{C}$ 로 상대적으로 작아 우드세라믹 표면온도의 하강은 탄화온도가 낮을수록 열 유지 정도가 높은 것으로 생각된다. 
귤박혼합율에 따른 혼합세라믹의 표면온도의 하강은 Fig. 6 과 같이 히터의 표면온도가 $60^{\circ} \mathrm{C}$ 에서 $42.2^{\circ} \mathrm{C}$ 로 감소함에 따라 귤박혼합율 $5 \%$ 시편은 $39.1^{\circ} \mathrm{C}$ 에서 $34.4^{\circ} \mathrm{C}$ 로, $15 \%$ 시편은 $40.1^{\circ} \mathrm{C}$ 에서 $34.4^{\circ} \mathrm{C}$ 로, $25 \%$ 시편은 $40.8^{\circ} \mathrm{C}$ 에서 $34.6^{\circ} \mathrm{C}$ 로 혼합율이 높을수록 세라믹 표면온도 하강속도가 커지지만 그 차이는 미비하다.

이상의 결과, 톱밥•귤박 혼합보드로 제조된 세라믹을 열적 성질과 관련되어 재료로 이용하기 위해서는 수지함침율이 $70 \%$ 이 상이고 소성온도 $1200^{\circ} \mathrm{C}$, 귤박 첨가율이 $5 \%$ 일 때 제조된 세라믹을 사용하는 것이 좋을 것으로 판단된다. 또한 본 연구에서 제조된 톱밥귤박 혼합세라믹은 열을 오랜 시간동안 유지하고 있기 때문에 면상발열체의 재료로 사용이 가능할 것으로 생각된다. 그러나 세라믹의 표면온도 변화는 시편의 밀도와 가장 밀접한 관련이 있을 것으로 판단되어 앞으로 수지 함침율, 탄화온도, 승온온도 등 세라믹 제조방법과 재료의 물성에 대한 연구와 전기적 특성 등을 정확히 검토할 필요가 있을 것으로 생각된다.

\section{2. 혼합세라믹의 원적외선 방사특성}

수지함침율 $60 \%$, 탄화온도 $800^{\circ} \mathrm{C}$ 로 탄화한 혼합세라믹의 귤박혼합율에 따른 원적외선 방사율과 방사에너지의 측정결과는

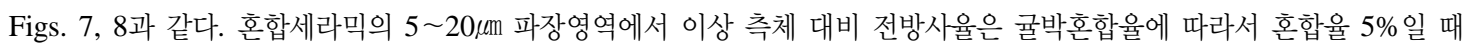
$0.929,10 \%$ 일 때 $0.927,15 \%$ 일 때 $0.929,20 \%$ 일 때 0.930 으로 귤박혼합율에 따른 원적외선 방사율은 귤박혼합율이 많을수록 약간 증가하였다. 방사에너지는 귤박혼합율 $5 \%$ 일 때 $375 \mathrm{~W} / \mathrm{m}^{2}, 10 \%$ 일 때 $373 \mathrm{~W} / \mathrm{m}^{2}, 15 \%$ 일 때 $374 \mathrm{~W} / \mathrm{m}^{2}, 20 \%$ 일 때 $375 \mathrm{~W} / \mathrm{m}^{2}$ 로 귤박혼합율 $5 \%$ 일 때 가장 컷으나 다른 시편과 비교하였을 때 큰 차이 없었다.

또한 수지함침율 $60 \%$, 귤박혼합율 $10 \%$ 로 제조된 보드를 탄화한 후 혼합세라믹의 탄화온도에 따른 원적외선 방사율과 방사에너지의 측정결과는 Figs 9,10 과 같다. 탄화온도 $600^{\circ} \mathrm{C}$ 일 때 $0.930,800^{\circ} \mathrm{C}$ 일 때 $0.927,1000^{\circ} \mathrm{C}$ 일 때 $0.927,1200^{\circ} \mathrm{C}$ 일 때 0.922 로 탄화온도가 증가할수록 원적외선 방사율은 감소하였다. 방사에너지는 탄화온도 $600^{\circ} \mathrm{C}$ 일 때 $374 \mathrm{~W} / \mathrm{m}^{2}, 800^{\circ} \mathrm{C}$ 일 때 $373 \mathrm{~W} / \mathrm{m}^{2}, 1000^{\circ} \mathrm{C}$ 일 때 $374 \mathrm{~W} / \mathrm{m}^{2}, 1200$ 일 때 $371 \mathrm{~W} / \mathrm{m}^{2}$ 로 탄화온도가 증가할수록 방사에너지가 낮아지는 경향이 있다. $\mathrm{Oh}(2016)$ 는 톱밥과 왕겨로 제조된 세라믹의 원적외선 방사율 측정에서 탄화온도가 높을수록 방사율은 감소한다는 결과와 같은 경향이였다. 이러한 원적외선 방사율은 규사 $(0.60 ~ 0.80)$, 맥반석( 0.90$), \mathrm{SiO}_{2}(0.83)$ 보다 높았으며, 숯( $(0.93)$, 그라파이트 (0.93), 세라믹코팅판(0.924) 등과 비슷하였다. 특히 Oh와 Byeon(2006)이 간벌재를 이용한 우드세라믹의 원적외선 방사율 측정값보다 높은 값을 보였다.

\section{4. 결 론}

본 연구에서는 제재과정에서 발생하는 톱밥과 농업부산물인 귤박을 이용하여 귤박혼합율 및 밀도별로 톱밥·귤박 혼합보드를 제조한 후 수지함침율, 탄화온도 및 귤박혼합율별로 세라믹화 하여 표면온도및 원적외선 방사 특성을 조사하였다.

1. 혼합세라믹의 표면온도 변화는 경과시간 10 분까지 급격히 상승하여 열전달 초기시간에 승온속도가 빠름을 알수 있었고, 경과시간 30분후의 표면온도는 탄화온도가 증가할 수록 높아졌고, 귤박혼합율은 표면온도 변화에 큰 영향을 미치지 않았다.

2. 원적외선 방사율은 귤박혼합율에 따른 일정한 경향이 없었고, 탄화온도가 증가 할수록 감소하였으며, 방사에너지 역시 원적외선 방사율과 비슷한 경향을 보였다. 